Man and Nature

L'homme et la nature

\title{
Modern Isms and the Lovejovian Universe
}

\section{Helen O. Molitor}

Volume 5, 1986

URI : https://id.erudit.org/iderudit/1011856ar

DOI : https://doi.org/10.7202/1011856ar

Aller au sommaire du numéro

Éditeur(s)

Canadian Society for Eighteenth-Century Studies / Société canadienne d'étude du dix-huitième siècle

ISSN

0824-3298 (imprimé)

1927-8810 (numérique)

Découvrir la revue

Citer cet article

Molitor, H. O. (1986). Modern Isms and the Lovejovian Universe. Man and Nature / L'homme et la nature, 5, 119-129. https://doi.org/10.7202/1011856ar

Copyright (c) Canadian Society for Eighteenth-Century Studies / Sociéte canadienne d'étude du dix-huitième siècle, 1986
Ce document est protégé par la loi sur le droit d'auteur. L'utilisation des services d'Érudit (y compris la reproduction) est assujettie à sa politique d'utilisation que vous pouvez consulter en ligne.

https://apropos.erudit.org/fr/usagers/politique-dutilisation/ 


\section{Modern Isms and the Lovejovian Universe}

Modern criticism of eighteenth-century British literature appears to have been one of the areas least affected by recent movements in the theory of literary criticism. It is still possible to say that most eighteenth-century specialists were brought up as some sort of formalist, either New Critic or Aristotelian. Our focus has been upon the poem as object, perhaps even specifically as Cleanth Brooks' Grecian urn. Formalist theory was usually modified by a healthy dose of intellectual history, since we were, in my opinion at least, fortunate to have such first-rate minds as those of A. O. Lovejoy and Samuel Holt Monk, to remind us that our objects were embedded in an historical context.

This critical world seems still very much our own. For example, in the mid-seventies, Roy Wolper, editor of The Scriblerian, reported that there were three, and only three, major tendencies he had noticed in Popeian criticism. We were, he said, producing studies of rhetoric, of historical and intellectual background and influences, and (the only 'new' type) of the relationships between work and author. ${ }^{1}$ In 1980, George Hahn, discussing critical work on Tom Jones, reported very similar results: interest in 'romance' elements, in eighteenth-century attitudes towards, and definition of, 'realism' (that is, in background and influences), and, again, one new element, interest in 'dynamic structure' (R.S. Crane's phrase) and hence in reader responses to works of the eighteenth century. ${ }^{2}$ 
Even in the 1970s, however, one can easily find extreme examples of other approaches: 'topomorphical analyses' and 'disambiguating texts'; attempts to apply, or misapply, Heisenberg's principle of physical uncertainty to intellectually created works of art; the belief that all writing is an attempt to 'facilitate slavery' - and hence the argument that, while Houyhnhnms do not write, the Yahoos do, because their 'decorative shit smearing' may be, may it not, the beginning of a script? ${ }^{3}$

Until very recently, the response of both our major reviewing magazines has been to dismiss the newer trends either with scorn or with cheerful insouciance, whether these trends seemed outrageous or just a little in advance of our times. Yet one finds, upon examining any group of modern criticism in our period that, whether outrageous or restrained, all share certain characteristics which would seem to contradict certain of our formalist assumptions, and to challenge the 'traditional' attitudes of the eighteenth century, in cosmology and thence in morality, epistemology, and metaphysics.

First, most schools of modern criticism are focused upon the less conscious and more shifting levels of the mind of the reader and/or author. The structuralist's rejection of apparent content in favor of mythopoeic form; the Freudian theory of art as a release of tension, as an expression of psychic desires; the phenomenological assertion of interest not in the external world per se but in mental perceptions of it, in the 'deep structures of the mind,' 4 so that the objective/subjective dichotomy is transformed into complete overlap; reader-response and authorinterrelational criticism: all these schools use the conscious, rational mind as an instrument for analyzing critical responses to a work of art, yet none are much interested in the conscious, rational reading or writing of a work, and many in fact would deny such acts are possible.

Second, despite a great variety of approaches and definitions of the work of art, a similar unity can be found lying behind this apparent diversity. Many phenomenologists, for example, seem often merely to go a step beyond the formalists or new Critics in their assertion that the 'essential work' is a pattern of themes. Yet that apparent emphasis upon recurring patterns in fact leads to a split between the 'meaning' of the work (what those patterns signified to the author) and its 'significance' (what they may mean to present readers). ${ }^{5}$

This assertion that different readings may coexist in time or over time is part of the modern movement that finally redefines the nature of the literary work. For the structuralists, or for many of them, details have meaning only in so far as they are fitted into the structure; relationships are all. The 'content' is the 'structure'; the 'structure' is the 'content.' (Take, for example, a most distinguished Canadian critic, Professor Nor- 
throp Frye. Prof. Frye does not like to be considered a structuralist, and certainly he differs in some major ways from Lévi-Strauss or the early Roland Barthes. Nevertheless, he announced some years ago that, first, THE mythopoeic structure of 'The Rape of the Lock' was the descent-tothe-underworld pattern and that, given that pattern, Clarissa's speech was an authorial intrusion - by implication at least, an authorial error. ${ }^{6}$ )

And that position is a way-station along the road to Barthes' latest position, to that of Derrida and other post-structuralists, that the literary work is the interplay of relationships, by nature unstable, shifting, dynamic. As Terry Eagleton puts it, the work cannot mean anything beyond the pleasure of 'the endless play of signifiers."

Thus, the work itself, the author, the reader, and the relationships among it, its author, and its readers, all become examples of Martin Buber's 'I-Thou' relationship. The 'I,' whether author or reader, is continuously mutable, as is the work of art which has become animated, either across time or in its own miniature cosmos. Hence the 'reality' of art in a sense coheres only in relationships, and these relationships reflect the belief that Being itself assumes the often illusionary, and always shifting, behaviour of Locke's secondary characteristics. ${ }^{8}$

These ideas on Art and on Being permeate much of modern criticism in one way or another. For example, the view of the eighteenth century with which we are most familiar is one based upon certain spatial metaphors; the most familiar one is, of course, the Great Chain of Being. This metaphor involves, as Lovejoy pointed out years ago, the problem of plenitude and creation. If God desires by his Nature the fullest possible creation, then did he create all at the one moment, and are our perceptions of species coming to being and dying away merely mistaken? Or is creation a continuing or continuous process, and is His creation now coming to perfection, or then, or never? But, despite such paradoxical problems, the Great Chain remained a fixed symbol of the fusion of physical substance and moral 'reality.' ${ }^{\prime}$

Within that cosmology, a piece of art was a permanent, a fixed object. We have been told repeatedly that the neo-classical comparisons were of poem and architecture or poem and painting. Over the last ten years there have been a number of studies pointing out that music was also used in such comparisons. Further, music then was thought of as a series of sounds, each 'frozen' in time, whereas music now is often conceptualized as a pattern of sounds and silences in time, once again, as a network of shifting relationships. ${ }^{10}$ Even further, we have recently been told that architecture itself was influenced in the eighteenth century by associative theory, so that building and viewer interrelate, interact. ${ }^{11}$ 
Along with scattered articles, go such investigations as those of Messieurs Alkon and Macey into time - time as used in works of fiction, time as conceived of by eighteenth-century writers and philosophers. ${ }^{12}$ Such investigations can be tucked away conveniently under 'additional intellectual history,' but they focus on non-spatial and hence on newly 'discovered' areas of the eighteenth century.

Similarly, in historical theory, we have moved not merely beyond Lecky and Namier, but to articles such as that of Peter Hughes on Vico. Hughes, noting that Vico asserts that man creates social history in his own image, then himself hypothesizes that literature is 'figurative history,' that the author or 'editor' creates a 'structure of reality.' Thus, historicism is transformed into a branch of structuralism, as Hughes hopes, he says, to free criticism from 'Aristotelian mimesis and Kantian aesthetics. ${ }^{13}$

In a similar way, reader-response and author-text-interrelational articles, some by distinguished scholars in our field, tend at least gently to move us into the new cosmos. They range from such familiar and scholarly works as Mack's The Garden and the City to Grant Holly's claim that the text of Gulliver's Travels is a 'perpetual metamorphosis' of which the reader partakes and in which he becomes editor, if not author. ${ }^{14}$

These ideas occur also in works about sensibilities and criticism in the eighteenth century itself. Murray Cohen, for example, dates a shift from an interest in the parallel between the order of words and the order of nature to a fascination with the connections between language ... and the structure of the mind' to the first half of the eighteenth century ${ }^{15}-a$ revision of dates for the romantic sensibility? Robert Holub believes a similar shift in audience aesthetics reflects the change from patronage to a middle-class 'marketplace'; the result of this shift creates a focus on the individual and subjective responses of an hypothetically ideal reader. ${ }^{16}$ And Michele Plaisant proposes a major shift in sensibility early in the eighteenth-century in authors, describing a thematic, semi-coded shift from physical to imaginative responses to the four elements. ${ }^{17}$

Finally, even the rhetorical and generic analyses, which would seem definitely old-fashioned, include both traditional and advanced semioticstructuralist approaches. Thus, Wolper and Hahn's references to 'rhetorical' and 'generic' conceal rather than reveal the changes in our area. Robert Schmiel, for example, uses a study of the classical trope 'adyaton' to reach an almost structuralist reading of Pope, ${ }^{18}$ while Guisseppe Galigani's analysis of 'Rape of the Lock' moves far beyond onomatopoeia and antitheses through what Galigani calls 'syntagmatic 
hyperbaton' and thence into signans, signatum, and almost pure structuralism. ${ }^{19}$

Thus, the new wave is upon us and among us. And in many ways it should be welcomed. It has pointed us towards new areas of the eighteenth century - towards unexplored metaphors, interests, ideas, which our previously systematic generalizations may have ignored or undervalued. In addition, it has provided us with techniques, perceptions, modes of criticism which may enable us to see more clearly even the writers, the areas, and the works already part of the familiar terrain. These new interests are most clearly seen in certain areas: studies of the persona and of satire, of biography and autobiography, of such specific topics as Johnson's prayers, and in studies of certain texts - $A$ Tale of $a$ $T u b$ which appears open-ended or Pamela and Clarissa which exist in two or more different manuscript or printed 'states.' 20

At the same time, of course, it creates difficulties. First, we have with us, as always, the crazies - and it becomes harder to distinguish the crazy from the newly significant when both use terms which simply affront our ideas of 'civilized' language. Some of the worst humoured reviews in The Scriblerian and in Eighteenth-Century Studies are reactions to critical jargon, even more than they are to critical craziness. ${ }^{21}$

Secondly, and far more crucially, the new modes of criticism rely upon philosophical assumptions which challenge traditional perceptions of eighteenth-century thought. The 'new physics' posits an un-Newtonian universe; hypothetical particularity becomes a potentially insubstantial network of force; sub-atomic particles, if they exist, behave acausually and paradoxically.22 Similarly, the new biology is non-Linnean. Developments in DNA research, in genetic technology whereby 'units of information' coded into the genetic structure of one species can be transplanted into another species, break down the traditional ideas of particular species and, in fact, of 'species' itself. Instead each biological creature may be seen, and can be created, as a unique composite of genetic information units, which may be changed in each generation either by complex recessive-dominant variations or by actual manipulation by human beings. ${ }^{23}$

This paper argues that the new modes of literary criticism entail certain psychological and metaphysical views of artist, reader, and literary work which parallel developments in the new physics and the new biology. William Ray's recent Literary Meanings: From Phenomenology to Deconstruction examines a similar thesis about recent criticism and the new epistemology. Significantly, Ray begins with the intention of recognizing and perhaps resolving the paradox between two meanings of 'meaning': first as 'historically bound act, governed by a particular inten- 
tion at a particular moment' and hence shifting from moment to moment, intention to intention (or intendifier), and second, as 'permanent textual fact,' that is, something close to the determinate, the New Critical object. Yet Ray concludes with the indeterminate hope that '...history and theory will merge with interpretation in an eclectic form of literary study less obsessed with controlling truth than (perhaps) with its ability to provoke the pleasure of new ideas. ${ }^{24}$

Thus, Ray moves from an attempt to reconcile different views of meaning to an implicit attack upon one of them, partly because he believes that 'established' figures in academia defend determinancy (and its supposed historical, critical, and textual 'truth') out of pure selfinterest. ${ }^{25}$ Similarly, though less politically, Murray Cohen believes the new methodologies will 'invigorate'a 'somewhat stale literature,' made dusty and remote by an older generation. ${ }^{26}$

One finds, in response, Donald Greene's 'fear' that The Eighteenth Century may have a post-structuralist bent. ${ }^{27}$ And G.S. Rousseau (himself no admirer of New Criticism, but undoubtedly an established scholar) suggests that phenomenologists, structuralists, and others create critical systems and terminologies as barriers to distance themselves from literature which they do not love. ${ }^{28}$

Clearly an examination of modern criticism of the eighteenth century suggests then that certain hostilities, both psychological and philosophical, underlie the current controversies about critical method. Undoubtedly, such wayward motives as self-interest and tenure-hunger exist, but the roots of antagonism lie deeper. As an example of these roots, I choose the works of Murray Krieger, for Krieger, although his books are little regarded by eighteenth-century specialists, seems to me seminal to any explanation of the controversy.

In 1971, Krieger argued:

The secret, existential awareness which I am attributing to Pope, then, need not involve the claim to ontological chaos instead of ontological order so much as it involves the awareness of the ungraspable transcience of the fleeting moment. The eighteenth-century cosmic-aesthetic structure depended utterly on a spatial imagination that could freeze all flux into unchanging universals where time is not. But - during moments now and then - can this view, what has been called "Naive Realism," help but be seen as naive by any human being who suffers and who knows he is to die, who feels time and the unrepeatable, unpausing passing of its unmarked instants (never an instance)? If all rushes past, how can anything but the passing-changing non-instance be phenomenally there? Is not this what makes (and has made) existentialists of us all? Long before Kant - and, since Kant, without him - we should have learned to distrust the easy metaphors of 
convenience invented by our spatial imagination as substitutes for those flowing temporal metaphors that elude our rational need for the boundaries making entity-hood. So before, or without, Kant we had to wonder whether that gorgeously symmetrical imaginative structure within which the well-behaved cosmos was expected to conduct its business, that structure with its spatial completeness, was not, after all, no more than imaginative: the product of our mind, of its need for comfort, and not existing on its own out there. ${ }^{29}$

Even as Krieger argues that a recognition of the partial indeterminancy of the physical world has no ontological consequences, he demonstrates that such consequences do appear. For, in his argument, a psychological awareness of flux in the physical universe means one can no longer be a 'naive Realist' (clearly a judgmental term). And, just as formalism and humanism seem interconnected, so that change in metaphysical belief leads Krieger in 1971 to a nihilist or at least an existentialist view of certain eighteenth-century writers.

By 1979, Krieger no longer tentatively suggests, rather he asserts that '... the monomyth of the eighteenth century ... is a myth we have imposed upon it ...' and that the writers of the eighteenth century actually shared the impulse towards indeterminancy, that they too were existentialists, and that they too recognised the Great Chain of Being, for example, not as a metaphorical expression of God's infinite and eternal order manifest even in flux, but as merely an existentialist metaphor, an illusion falsely imposed upon chaos. ${ }^{30}$

Krieger's work on the eighteenth century is seminal, then, in several ways. First, Krieger supposes that, for whatever motives, the scholarly establishment has imposed a 'monomyth' upon the century; in Ray's terms, it has tried to control 'the truth.' And we may, in part, have done so. I would, of course, argue that scholars like Lovejoy and Monk had no such intention. Rather, by showing that certain intellectual patterns did appear, they meant to grant us freedom - freedom from having to define repetitiously those patterns every time part of them reappeared, and freedom also to see that they did not pertain to all writers, to all works, at all times or in the same ways. Yet Krieger's belief in an authoritarian monomyth lies behind the writing of many of the new critics.

Secondly, Krieger believes that modern existentialism is truth. Just as students over the next few years will find themselves accepting the new physics, the new biology, as truth, so the advocates of indeterminacy, of relativism, of existentialism seem, paradoxically, to wish to impose their own indeterminacy upon others. And those others include not only the moderns but the ancients as well. ${ }^{31}$ 
Therein lies the crux of the difficulty created by the new methodologies. Each side of the debate believes that 'The Other' is both alien and a usurper. The older critics are said, from self-interest and an excessive love of determinism and tradition, to have created a monomythic distortion of the eighteenth century and its literary works. The newer critics, also from self-interest and an excessive love of elaborate critical vocabularies and theories, are believed to be in the process of creating another, and antagonistic, monomyth in which the eighteenth century and its works are indeterminate and existentialist. ${ }^{32}$

Yet the works of the eighteenth century are more pluralistic both among and within themselves than any single system can in fact describe. Certainly the people of that century shared the pains of being human, yet some of them shared also strong beliefs in certain meaningful patterns and principles. Thus, with Krieger they may certainly have felt the uncertainty of life, but they may not all then have become existentialists - or post-structuralists. Even as a very young man, Pope knew perfectly well that 'Time conquers All, and we must Time obey,' but, in his middle years, he wrote also:

All are but Parts of one stupendous Whole, Whose Body Nature is, and God and Soul.... ${ }^{33}$

HELEN O. MOLITOR

University of Manitoba

\section{Notes}

1 Wolper's unpublished paper is summarized by Adina Forsgren in The Scriblerian 7 (Autumn 1974) 53

2 H. George Hahn, 'Main Lines of Criticism of Fielding's Tom Jones, 1970-1978,' British Studies Monitor 10 (Spring and Summer 1980) 8-35

3 Essays referred to are: Roy T. Ericksen, 'The Last Image of the Troubled Heap: From Chaos to Coherence in Pope's Epistle to Cobham,' Studia Neophilologica 52 (1980) 299-311; Deborah Linderman, 'Self-Transforming Ironies in Swift's A Tale of a Tub,' Comparative Literature Studies (Illinois) 16 (1979) 69-78; Peter E. Lewis, 'The Uncertainty Principle in The Beggar's Opera,' Durham University Journal 41 (1980) 143-6; Terry J. Castle, 'Why the Houyhnhnms Don't Write: Swift, Satire, and The Fear of the Texts,' Essays in Literature (Western Illinois University) 7 (1980) 31-44. 
4 The idea that literature reveals deep, generally unconscious, structures of the mind was originally Edmund Husserl's. Modern developments of it can be seen in the works of a number of phenomenologists, perhaps most readily in Georges Poulet, part II of 'The Phenomenology of Reading,' New Literary History: A Journal of Theory and Interpretation 1 (1969), reprinted in Critical Theory Since Plato, ed. Hazard Adams (Chicago: Harcourt, Brace, Jovanovich Inc. 1971).

5 E.D. Hirsch, Jr., in his Validity in Interpretation (New Haven: Yale University Press 1967) was the first to define this difference between meaning and significance.

6 Professor Frye specifically stated these ideas at a seminar at the University of Calgary in the early seventies, but they appear implicitly in his work as early as Anatomy of Criticism (Princeton: Princeton University Press 1957), 183 where he identifies 'The Rape' as a work expressing 'the green earth myth.'

7 Terry Eagleton, Literary Theory: An Introduction (Oxford: Basil Blackwell, 1983) 138

8 If Marxism is seen as a philosophical attempt to moralise time, to discover a pattern of meaning in, or to impose one upon, the apparently mindless flow of history, then Marxist-Leninist criticism can be considered structuralist in methodology (tracing economic motifs and themes, for example) and phenomenological in motive (attempting to reveal submerged ideologies/assumptions which shape the imagined world and its critics).

9 A. O. Lovejoy, 'The Temporalizing of The Chain of Being,' in The Great Chain of Being (New York: Harper and Row 1965) 242-87

10 See, for example, Johnson's Dictionary, 4th ed., where 'Musick' is defined as The science of harmonical sounds' and quotations include Shakespeare's 'sweet sounds' and Spenser's 'silver sound.' Or Thomson's The Seasons, where, in 'Spring,' 11. 590-613, even the discordant cries of jay and rook constitute part of musical 'Concord.' While, as Professor G. Seamans of the Department of Music at the University of Auckland pointed out at the CSECS conference, at least some eighteenth-century composers were intensely aware of the importance of silences, none of them (as Professor John Rempel of the University of Manitoba reminded us) dared the bravado of John Cage's 4'33" - a modern piece consisting of four minutes and thirty-three seconds of silence. In other words, the change I here mention is relative, not absolute.

11 John Archer, 'The Beginning of Association in British Architectural Esthetics,' Eighteenth Century Studies 16 (1983) 241-64

12 Paul Alkon, Defoe and Fictional Time (Athens, GA: University of Georgia Press 1979); Samuel L. Macey, Clocks and The Cosmos: Time in Western Thought and Life (Hamden, CT: Shoestring Press 1980). See also Eighteenth Century Life, 8, n.s. (1982) for more recent articles by Alkon and Macey.

13 Peter Hughes, 'Creativity and History in Vico and his Contemporaries,' in Giorgio Tagliacozzo and Donald P. Verene, eds. Giovanni Vico's Science of Humanity (Baltimore: Johns Hopkins University Press 1976) 155-69

14 Grant Holly, 'Travel and Translation: Textuality in Gulliver's Travels,' Criticism 21 (1979) 134-52 
15 Murray Cohen, Sensible Words: Linguistic Practice in England, 1640-1785 (Baltimore: Johns Hopkins University Press 1977)

16 Robert C. Holub, 'The Rise of Aesthetics in the Eighteenth Century,' Comparative Literature Studies (Illinois) 15 (1978) 271-83

17 Michele S. Plaisant, La Sensibilité dans la póesie anglaise au debut du XVIIIe siècle: Evolution et transformations (Paris: Champion 1975)

18 Robert Schmiel, 'The "Impossible" in Pope's Rape of the Lock,' The Humanities Association Review/La Revue de l'Association des Humanites 29 (1978) 147-52

19 Giuseppe Galigani, Il 'Rape of the Lock' del Pope: quattro voci di un contrapunto (Pisa: Giardini 1976). See also note 21, below.

20 Bibliographical information on the persona can be found in the notes accompanying Howard Weinbrot's 'Masked Men and Satire and Pope,' Eighteenth-Century Studies, 16 (1983) 265-89. Recent commentary on satire is perhaps most readily available in the reviews of Edward A. and Lillian D. Bloom's Satire's Persuasive Voice (Ithca, NY: Cornell University Press 1979). William C. Dowling's Language and Logos in Boswell (Princeton: Princeton University Press 1981), and Allan Ingram's Boswell's Creative Gloom (Totowa, NJ: Barnes and Noble 1982) represent the use of new methodologies in the treatment of biography. Arguments for open-ended, indeterminate texts for A Tale of a Tub and/or Gulliver's Travels are the bases of the Linderman article (note 3, above) and of Charles Pullen's The Role of the Reader of Eighteenth-Century Literature and Swift's $A$ Tale of $A$ Tub,' Eighteenth-Century Studies, 1 (1975) 280-9 and Robert W. Uphaus, The Impossible Observer: Reason and the Reader in Eighteenth-century Prose (Lexington, KY: University of Kentucky Press 1979). The most striking examples of Richardsonian 'new' criticism are Terry Castle's Clarissa's Ciphers (Ithca, NY: Cornell University Press 1982), and William Beatty Warner's Reading Clarissa (New Haven: Yale University Press 1979). For a commentary on the range of Clarissian criticism, see Sue Warrick Doederlein, 'Clarissa in the Hands of the Critics,' Eighteenth-Century Studies 16 (1983) 404-14.

21 See, for example, the reviews of Paul D. McGlynnis 'Microcosm and the Aesthetics of Eighteenth-Century British Literature,' in The Scriblerian 11 (1979) 36, or of Giuseppe Galigani's 'Some Homologies Between The Rape of the Lock and the Visual Arts,' The Scriblerian 16 (1983) 14-15.

22 David Highnam's 'Jacques le fataliste; Narrative Structure and new Physics,' Man and Nature/L'Homme et la Nature II (1984) is the first attempt, to my knowledge, actually to use the 'new physics' as a metaphor with which to examine an apparently indeterminate text.

23 See Jeremy Rifkin's recent 'best seller,' Algeny, for a lively and opinionated evaluation of the epistemological and moral consequences of the new genetics.

24 (Oxford: Basil Blackwell 1984), 2 and 212

25 Ibid., 207-11

26 Murray Cohen, 'Eighteenth Century English Literature and Modern Critical Methodologies,' The Eighteenth Century 20 (1979) 5-23

27 In his review of the various specialist magazines, The Scriblerian, 11 (1979), responded to by the editor of TEC, in The Scriblerian, 12 (1979). 
28 G. R. Rousseau, in his evaluation of Marjorie Nicolson's contribution to eighteenth-century studies, The Scriblerian 10 (1977) 85-7

29 Murray Krieger, The Classic Vision (Baltimore: Johns Hopkins University Press 1971) 123

30 Much of Krieger's work implies these assertions, but Krieger presents them most compactly and vividly in "Trying Experiments upon our Sensibility": Dogma and Doubt in Eighteenth-Century Literature,' in his Poetic Presence and Illusion: Essays in Critical History and Theory (Baltimore: Johns Hopkins University Press 1979).

31 See Steve Giles in 'Delimited by Discourse,' Renaissance and Modern Studies 27 (1983) 147-8, for an abstract, philosophical discussion of the absolutism of relativism.

32 See also Krieger's 'The Existential Basis of Contextual Criticism,' in Hazard Adams, ed., Criticism Theory Since Plato (Chicago: Harcourt, Brace, Jovanovich, Inc. 1971), in which Krieger attempts to reconcile 'objective' and 'subjective' critics, but ends by asserting the 'truth' of what appears to be an intertextual approach. Such recent works as Vincent Newey's Cowper's Poetry: $A$ Critical Study and Reassessment (Totowa, NJ: Barnes and Noble 1982) identify an eighteenth-century writer as a 'proto-existentialist' and 'proto-Heideggerian' identifications which catch the attention, and rouse the distrust, of the reviewer (Eighteenth-Century Studies 18 [1984] 89-92). Pope's response to such identifications - and to the new genetics - may be symbolised by his reference to '...a monster of a fowl,/something betwixt a Heideggre and owl...,' though his protoHeidegger is an eighteenth-century London theatre-manager (Dunciad, I, 11. 289-90).

33 The first quotation is from the closing lines of the 'Winter' pastoral, the second from An Essay on Man, I, 267-8. 